\title{
The Hydrogen Economy in the 21st Century: A Sustainable Development Scenario
}

L. Barreto

International Institute for Applied Systems Analysis, Laxenburg, Austria

A. Makihira

Tokyo Electric Power Company, Japan

K. Riahi

International Institute for Applied Systems Analysis, Laxenburg, Austria

RR-03-001

March 2003

Reprinted from the International Journal of Hydrogen Energy, 28 (2003) 267-284. 
Research Reports, which record research conducted at IIASA, are independently reviewed before publication. Views or opinions expressed herein do not necessarily represent those of the Institute, its National Member Organizations, or other organizations supporting the work.

Reprinted with permission from the International Journal of Hydrogen Energy, 28 (2003) 267-284.

Copyright (C) 2002 International Association for Hydrogen Energy.

All rights reserved. No part of this publication may be reproduced or transmitted in any form or by any means, electronic or mechanical, including photocopy, recording, or any information storage or retrieval system, without permission in writing from the copyright holder. 


\title{
The hydrogen economy in the 21 st century: a sustainable development scenario
}

\author{
L. Barreto ${ }^{\mathrm{a}, *}$, A. Makihira ${ }^{\mathrm{a}, \mathrm{b}}$, K. Riahi ${ }^{\mathrm{a}}$ \\ anternational Institute for Applied Systems Analysis, Schlossplatz 1, Laxenburg A-2361, Austria \\ ${ }^{\mathrm{b}}$ Tokyo Electric Power Company, 1-3 Uchisaiwai-cho 1 Chome, Chiyoda-ku, Tokyo 100, Japan
}

\begin{abstract}
A long-term hydrogen-based scenario of the global energy system is described in qualitative and quantitative terms here, illustrating the key role of hydrogen in a long-term transition toward a clean and sustainable energy future. In an affluent, low-population-growth, equity and sustainability-oriented $\mathrm{B} 1-\mathrm{H}_{2}$ world, hydrogen technologies experience substantial but plausible performance and costs improvements and are able to diffuse extensively. Corresponding production and distribution infrastructures emerge. The global hydrogen production system, initially fossil based, progressively shifts toward renewable sources. Fuel cells and other hydrogen-using technologies play a major role in a substantial transformation toward a more flexible, less vulnerable, distributed energy system which meets energy needs in a cleaner, more efficient and cost-effective way. This profound structural transformation of the global energy system brings substantial improvements in energy intensity and security of supply and results in an accelerated decarbonization of the energy mix, with subsequent relatively low climate impacts. Such energy-system path might still not be sufficient to protect against the risk of high climate sensitivities, but hydrogen-based technologies emerge as flexible options for the energy system and, thus, would be prime candidates for a risk management strategy against an uncertain climate future.
\end{abstract}

(C) 2002 International Association for Hydrogen Energy. Published by Elsevier Science Ltd. All rights reserved.

Keywords: Hydrogen economy; Sustainable development; Long-term scenario

\section{Introduction}

The concept of sustainable development has evolved into a guiding principle for a livable future world where human needs are met while keeping the balance with nature. Addressing the challenge of sustainability requires a long-term perspective and the integration of many elements. Energy is one of them. Driving the global energy system into a sustainable path is progressively becoming a major concern and policy objective $[1,2]$. The emergence of a sustainable global energy system, however, is a gradual long-term process that will require a profound transformation of its current structure.

\footnotetext{
* Corresponding author. Tel.: +43-2236-807578; fax: +432236-71313.

E-mail address: barreto@iiasa.ac.at (L. Barreto).
}

Although many alternative sustainable energy pathways may emerge, the so-called "hydrogen economy" has received particular attention. A hydrogen-based energy system is regarded as a viable and advantageous option for delivering high-quality energy services in a wide range of applications in an efficient, clean and safe manner while meeting sustainability goals [3]. Hydrogen also provides an ideal complement to electricity. Both are premium quality energy carriers, do not contain carbon and generate little or no polluting emissions at the point of use. Electricity, however, is at disadvantage when storage is required while hydrogen could be well suited for those applications.

Its versatility is enhanced by the fact that it can be produced from a variety of fossil and non-fossil primary resources. Thus, supply infrastructures can be developed according to the feedstocks available in different regions. This can bring concrete energy security benefits and could 
facilitate the transition to a sustainable energy system. In the initial phase of a "hydrogen economy", hydrogen could be produced from the current competitive fossil fuels. At a later stage, the production system could evolve toward renewable resources.

In such way, it would become an ideal vehicle to "add value" to renewable resources and make them suitable to provide high-quality energy services [4]. At the same time, making hydrogen out of renewable sources would drive its production system toward a sustainable trajectory in the long term.

Hydrogen has also a strategic importance in the pursuit of a low-emission, environment-benign, cleaner and more sustainable energy system. On the one hand, the introduction of highly efficient and clean hydrogen-based end-use technologies would help to reduce final energy consumption and, in addition, could provide local and regional environmental benefits (e.g. regarding air pollution). On the other hand, hydrogen can be produced from carbon-free resources or from fossil fuels combined with carbon separation and sequestration. Thus, hydrogen could contribute substantially to the reduction of greenhouse gas (GHG) emissions.

In the distant future, hydrogen could become an important energy commodity at the global level. Achieving such a goal, however, will require significant cost and performance improvements in production, storage, conversion, transportation and end-use technologies. Only a sound combination of research, development and demonstration efforts, as well as commercial deployment would lead to the necessary technology improvements and cost reductions [5]. Intensive $R \& D$ efforts are still required in a number of areas [6]. In addition, the profitable commercialization of hydrogen technologies will require market strategies that stimulate the coordination of different market segments.

Niche markets, for example, where convenience, reliability, and environmental criteria are important, could make hydrogen technologies attractive, and are most likely to play a critical role in their diffusion. Fuel cells, for instance, already find acceptance in applications where their cleanliness, reliability and fuel flexibility compensate for their higher costs, for example supplying electricity to sensitive loads with stringent reliability-of-supply standards.

Distributed stationary co-generation (joint production of power and heat) applications in buildings and industry, together with selected mobile transportation applications (e.g. public and private vehicle fleets) could be the key to stimulate the initial growth of the hydrogen market. Potential synergies between the buildings and vehicles markets could be used to make hydrogen a more attractive alternative and help to overcome the initial infrastructure barrier [7]. Specifically, hydrogen production appliances installed to serve buildings needs could also be used as refueling sources for vehicles. Fuel cell powered vehicles, in turn, could be a source of electricity while parked. A dynamic growth in these niche markets would justify the deployment of large-scale production and transportation facilities later on, when demand increases and becomes more geographically dense.
A number of studies have analyzed the perspectives and possible strategies for a transition toward a hydrogen-based energy system, the so-called "hydrogen economy" (e.g. [3,7-10]. Structural changes of energy systems, however, take a long time. A transition from niche markets to a fully developed "hydrogen economy" would span over many decades. Thus, adequate quantifications of long-term trends and structural changes in the global energy system compatible with the successful diffusion of hydrogen technologies are required.

This very long-term perspective is adopted here in order to explore the role of hydrogen technologies in a future scenario of energy, economic and environmental development. Our "hydrogen-economy" scenario is based upon the IIASA-SRES B1 [11] scenario with updated information on hydrogen technology characteristics gathered from a technology assessment.

The scenario (labeled B1- $\mathrm{H}_{2}$ ) portrays a world with high environmental and social consciousness combined with globally coordinated efforts to achieve sustainable development and to reduce income disparities across regions. Population growth is restrained while economic growth is vigorous. Technological change plays an important role and diffusion of clean technologies is fast. Given these characteristics, a B1- $\mathrm{H}_{2}$ world is a fertile ground to nurture an emerging sustainable "hydrogen economy".

The B1- $\mathrm{H}_{2}$ world outlines hydrogen's potential contribution to the global energy mix in the 21 st century if favorable conditions for its penetration were in place. Clearly, from today's perspective, substantial hurdles still have to be surmounted. Thus, it may be regarded as an optimistic, although insightful, perspective. In $\mathrm{B} 1-\mathrm{H}_{2}$, provided there were significant but plausible technology enhancements, hydrogen becomes the main final-energy carrier by the end of the $21 \mathrm{st}$ century and a diversified and sustainable portfolio of production and end-use technologies emerges and develops.

The paper is structured as follows. Section 2 presents the narrative "storyline" that qualitatively delineates the main characteristics of our hydrogen-based energy future. Our quantification of the hydrogen economy consistent with the scenario "storyline" is presented in Section 3. Model and scenario assumptions are described and results from the scenario analysis are discussed. Finally, Section 4 concludes. Appendix A presents a list of the aggregated electricity generation technologies included in our analysis.

\section{The storyline of a future running on hydrogen}

This section presents the scenario storyline based on which we have adopted a set of internally consistent assumptions to calculate the scenario quantification presented in Section. 3. The storyline represents a description of how a future consistent with the hydrogen economy might unfold, and gives a brief characterization of its main driving forces. First, we present some qualitative descrip- 
tion illustrating the economic, technical, environmental and social developments in the scenario. Finally, we will focus on the role of hydrogen and summarize the main features for the hydrogen deployment and its eventual success.

As explained above, the scenario developed here builds upon the IIASA-SRES-B1 quantification [11] with an updated set of hydrogen technologies characteristics. In view of that, we have chosen to label it the $\mathrm{B} 1-\mathrm{H}_{2}$ scenario. As mentioned before, we will use the context of the B1- $\mathrm{H}_{2}$ scenario to explore a possible "ceiling" for the contribution of hydrogen to the energy system under favorable conditions.

The B1- $\mathrm{H}_{2}$ world follows a sustainable-development path, where environmental concerns at local, regional and global levels remain high in the policy agenda; priority is given by governments and economic actors to the development and diffusion of clean, highly efficient technologies. The evolution of a collective environmental consciousness drives to strengthen the local participation in planning and decision-making, and to the emergence of sustainable communities, eager and able to make their own nature-benign choices. This gives a substantial impulse to versatile, decentralized, less vulnerable, highly efficient and environmentally compatible energy technologies. In these circumstances, a global hydrogen-based energy system emerges as a sensible alternative to contribute to the achievement of long-term energy sustainability goals. Hydrogen technologies are intensively developed and their introduction to the market actively pursued.

Social actors at many different levels embrace the principles of sustainability and pay increased attention to social and environmental aspects of development. Improved efficiency of resource use (i.e. "dematerialization"), equity, development of social institutions and environmental protection become actively pursued goals. Steadily rising education levels result in a transition toward a high-skilled labor force and a better integration of women in the labor markets. Development takes place with a strong emphasis on promoting, and productively using, social capital [12], as well-functioning social networks, institutions, associated norms and (shared) values are progressively seen as an essential pre-condition for economic prosperity and sustainability.

Technology is acknowledged as an essential instrument to achieve sustainability and energy security goals and, thus, technological change plays an important role. Public-private alliances together with international collaboration and coordinated technology policies help to share the costs and overcome the risks of developing innovative technologies. As a result, significant levels of technology spillover occur. Promotion of international RD3 partnerships ${ }^{1}$ and introduction of incentive-based mechanisms allow development

\footnotetext{
${ }^{1} \mathrm{RD} 3$ is an acronym for research, development, demonstration and deployment [5]. It refers to strategies that recognize the importance of combining "technology push" with "demand pull" mechanisms to promote the diffusion of emerging technologies.
}

and fast diffusion of cleaner and more efficient technologies. Co-operation schemes permit local capacity building and successful technology transfer toward developing regions.

The combination of technical and organizational change results in high levels of material and energy saving, reductions in pollution and improvements in labor productivity. Together with significant energy efficiency improvements, this translates into a relatively small increase in energy demands. Environmental quality is high, as potentially negative effects are dealt with in an effective manner. Although explicit climate policies are not in place, the combination of proactive environmental measures at the local, regional and international levels results in the rapid introduction of hydrogen technologies and, consequently, relatively low carbon emissions.

In the distant future, hydrogen will have become the preferred energy carrier for a number of applications, providing a suitable complement to electricity in delivering energy services in a clean and cost-effective way. $\mathrm{H}_{2}$-powered appliances will have spread through residential complexes, transportation technologies and industrial applications supported by a well-developed infrastructure of production, transportation, storage and distribution.

Other developments have accompanied and encouraged their diffusion. Specifically, stimulated by the shift toward open and competitive markets, the electricity system experienced an institutional and regulatory revolution to accommodate the emerging, increasingly competitive small-scale decentralized generation alternatives. A distributed system has emerged that ensures the high reliability and power quality standards the knowledge-oriented digital society requires and that adequately responds to energy security issues. Flexible and inexpensive automation, metering and communication technologies allow easily redirecting power flows, as disperse generation sources go in and out of the network.

Fuel cells and related technologies are well developed, mature and have become ubiquitous. Hand-held computing and communication devices are powered by miniature, circuit-like and easily "rechargeable" fuel cells (using for instance a hydride cartridge). Ultra-light, very efficient and low-polluting cars powered by inexpensive low-temperature fuel cells circulate in the streets and also operate as small distributed electricity generators, injecting electricity to the grid while parked.

A significant share of electricity generation will be based on these vehicular fuel cells. The load factor of a car is 3-6 percent which means that the car is parked 94-97 percent of its life time-usually close to where the drivers stay anyway: at home, work or in a restaurant. These car-driver locations are precisely where the demand loads arise. Current global automotive generating capacity is approximately one order of magnitude larger than total utility and non-utility electricity generating capacity. Thus, spare and reserve capacity would not be a constraint. Where convenient, hydrogen micro-turbines and high-temperature fuel cells will cover the heating and electricity needs of larger 
commercial and industrial complexes, which are allowed to trade their power surpluses in the spot market.

\section{A hydrogen scenario-quantification and results}

The $\mathrm{B} 1-\mathrm{H}_{2}$ scenario portrayed here builds upon the storyline given in Section 2 and the long-term IIASA-B1 scenario described and quantified in [11]. For the quantification of the B1- $\mathrm{H}_{2}$ scenario, we used GDP, population, technology characteristics and resource availability consistent with the SRES-B1 scenario, and updated all relevant information for hydrogen technologies according to a technology assessment briefly described in Section 3.2. We will first describe the main characteristics of these driving forces, whose interaction plays a significant role in shaping the path followed in the $\mathrm{B} 1-\mathrm{H}_{2}$ world, and then proceed to highlight selected results on the emerging structure of the global energy system and its environmental impacts.

The analysis has been carried out with MESSAGE, a systems-engineering optimization model with a detailed technological representation, and MACRO, a top-down stylized macro-economic model [13]. In MESSAGE-MACRO, the global energy system is disaggregated in 11 regions. For simplicity, however, the discussion here is carried out mainly at the global level and, where appropriate, for the following four aggregate regions:

- The OECD90 region groups the countries belonging to the OECD in 1990.

- The REF region brings together the economies-in-transition in the Former Soviet Union and Eastern Europe.

- The ASIA region represents the developing countries in the Asian continent.

- The ALM region covers the rest of the world, grouping countries in sub-Saharan Africa, Latin America and the Middle East.

\subsection{Demographic and economic assumptions}

The population trajectory underlying this scenario corresponds to a variant of the low-population projection reported by Lutz [14], where low-fertility and low-mortality assumptions are combined with central interregional migration trends. Extensive aging occurs in all regions and global population peaks at 8.7 billion in 2050 and declines afterwards reaching 7.1 billion by the end of the 21 st century ( 5.6 billion in developing countries and 1.4 billion in industrialized ones). This scenario is consistent with recent analyses, which have found a significant probability that the world population will stop growing well before the end of the century [15].

Closely linked to this demographic trend, economic development is balanced and vigorous and deliberate efforts to reduce interregional income inequalities prove effective. With a significant economic "catch up" in the develop- ing regions, the gap in per capita income between them and the industrialized regions narrows. A gross world product (GWP) of around US\$329trillion (1990US\$ at market exchange rates) is reached by 2100 , which presupposes an optimistic global average growth rate of 2.5 percent per annum. This substantial growth is fueled, among other factors, by technological and organizational changes that result in large labor productivity increases.

A distinctive feature of this scenario is that economic development emphasizes social and environmental issues. Governments and businesses support and engage themselves in activities to boost eco-efficiency and social well-being. In this world, a large part of the gains are invested in improving resource efficiency, achieving social objectives within and between countries, strengthening social institutions, building collaborative networks and ensuring environmental protection.

Income per capita also rises at a fast pace reaching an average global value of US $\$ 15,600$ in 2050 and US $\$ 46,600$ in 2100 (1990US\$ at market exchange rates), being a significant fraction spent in services rather than material goods. This is a fast-converging world. By the end of the century, the average income per capita in the developing world reaches US $\$ 40,600$ or 59 percent of that of the industrialized ones (US\$69,300).

\subsection{Technological change}

Technological change is among the main drivers of long-term productivity and economic growth [16]. Over long time horizons, performance of technologies is considerably improved (efficiencies increased, unit costs reduced, etc.) and new technologies are introduced. Characteristic for technological learning is that costs typically decrease in line with accumulation of experience (measured as a function of cumulative output).

In the systems-engineering MESSAGE model [13], technical, economic, and environmental parameters for over 400 technologies are specified explicitly. Technological change is introduced exogenously, that is, performance of technologies improves at predefined rates over time. Compared to historical experience [17], the resulting learning rates for renewable technologies in the $\mathrm{B} 1-\mathrm{H}_{2}$ scenario are on the optimistic end. For example, the learning rate for photovoltaic power plants in $\mathrm{B} 1-\mathrm{H}_{2}$ is nearly 20 percent, i.e. cost reductions of 20 percent per doubling of cumulative installed capacity. This is a learning rate comparable to estimated historical learning rates from 1968 to 1998 at the global level [18]. Fossil-based technologies also improve their performance and cost characteristics but, depending on the fuel, the pace is different. Coal-based technologies experience only low-to-moderate improvements, reflecting the decreasing environmental and social attractiveness of its use, while oil- and gas-based ones do so at average-to-high rates.

As for hydrogen technologies, we have conducted an in-depth survey of the published literature and publicly 


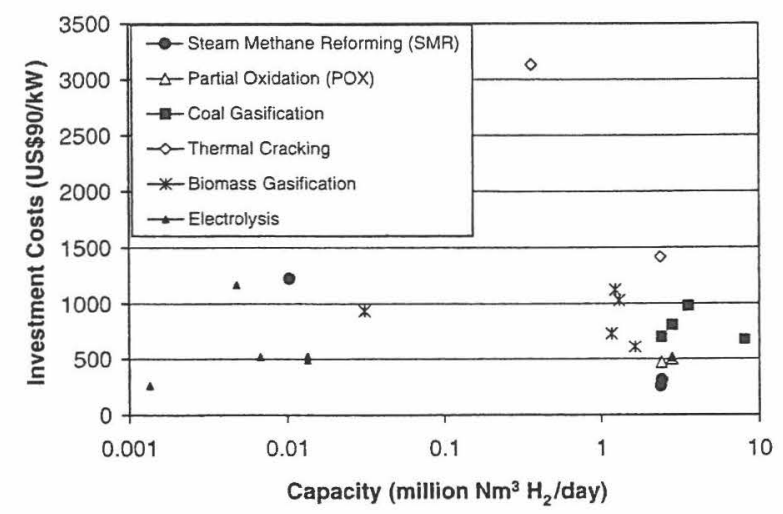

Fig. 1. Investment cost of hydrogen production plants as a function of production capacity as reported by a number of sources in the literature [19].

available databases related to the whole hydrogen energy chain, i.e. from hydrogen production to end-use technologies, with emphasis on the examination of cost estimates. As an example, Fig. 1 shows the investment cost of different hydrogen production plants as a function of the hydrogen capacity reported by different sources in the literature. In the capacity of over one million $\mathrm{N} \mathrm{m}^{3}-\mathrm{H}_{2} /$ day, SMR technology has the least-expensive investment cost in comparison to other hydrogen production methods. The survey is described in detail in [19].

Based on such survey, we have selected cost and efficiency parameters for the hydrogen-based technologies included in our scenario. The survey comprised not only those hydrogen technologies currently available but also some advanced promising processes. However, for many of the processes still in early stages of development, cost estimates are not available or unreliable and, therefore, they were not included. Still, we recognize that new technologies could emerge that could trigger a profound transformation of the production, storage, transportation and use of hydrogen.

The development of investment costs for the main hydrogen production technologies in the $\mathrm{B} 1-\mathrm{H}_{2}$ scenario is given in Fig. 2. The initial costs in the base year (1990) were selected from the range of cost estimates summarized in the technology assessment. We consider the following technologies for the conversion of secondary and primary fuels into hydrogen: (1) electrolysis (using all types of renewable and fossil electricity as input), (2) coal gasification, (3) steam methane reforming of natural gas, (4) partial oxidation of fuel oil, (5) solar thermal cracking, (6) biomass gasification and (7) cogeneration of electricity and hydrogen via high-temperature nuclear reactors. ${ }^{2}$ Consistent with the

\footnotetext{
${ }^{2}$ Note that for the literature survey, cost data for hydrogen production from solar thermal cracking and from high-temperature nuclear reactors were not available. For these technologies, we adopted the costs from the SRES-B1 scenario $[11,20]$.
}

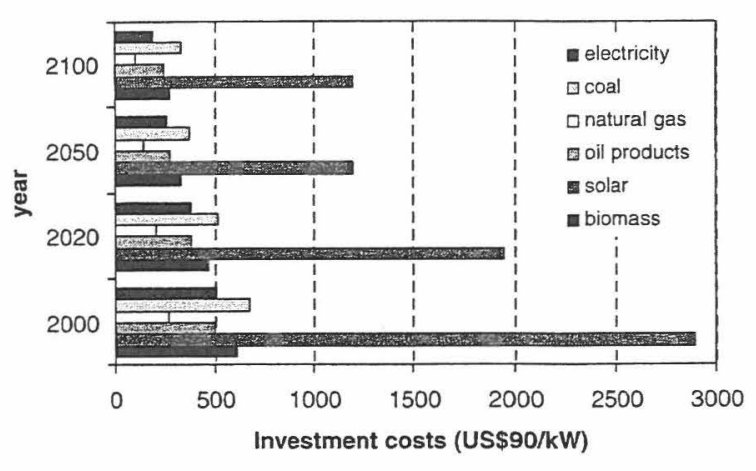

Fig. 2. Investment costs for the main hydrogen production technologies in the $\mathrm{B} 1-\mathrm{H}_{2}$ scenario by source. We assumed that investment costs of high-temperature reactors with hydrogen co-generation stay constant over time $(2450 \mathrm{US} \$ / \mathrm{kW})$ consistent with the historical experience for nuclear technologies.

storyline of the scenario, all hydrogen technologies experience significant but still plausible cost improvements.

\subsection{Resource availability}

Assumptions on the fossil-fuel resource base are based on the estimates reported by Rogner [21]. The categorization distinguishes between conventional and unconventional reserves and resources and reflects increasing degrees of geological uncertainty and decreasing degrees of economic attractiveness. Consistent with the environmentally conscious and resource-conservation drive underlying this scenario, a conservative availability of oil and gas resources is assumed. The oil resource base is limited to conventional resources and potential for their enhanced recovery. This corresponds to categories I-IV in [21]. Categories I-III represent conventional reserves and resources. Category IV represents the potential for enhanced recovery of the conventional resources.

As for natural gas, both conventional and unconventional occurrences are taken into account, but the categories labeled as "additional occurrences", for which the highest uncertainty exists and which are not likely to be exploited with the foreseeable technological developments, are not included.

Coal resources are also based on [21] and are considered abundant. Coal extraction costs are assumed to rise in regions with large shares of deep mines and high population densities but they remain relatively low in regions rich in surface coal reserves.

More important than the assumptions on the ultimate resource base is, however, the actual resource use and the question whether the (world/regional) resource constraints were binding. The cumulative resource consumption, shown in Table 1, results from the interplay of the different driving forces involved in the scenario and represents a more appropriate indicator than the exogenously specified resource base. Table 1 summarizes the global hydrocarbon resource availability and the cumulative fossil fuel use of the $\mathrm{B} 1-\mathrm{H}_{2}$ scenario. 
Table 1

Eight categories of conventional and unconventional oil and gas reserves, resources and additional occurrences in zetajoules, $\mathrm{ZJ}$ (10 ${ }^{21} \mathrm{~J}$ ). The table shows which of the categories are deployed in the B1- $\mathrm{H}_{2}$ scenario and compares cumulative use from 1990 to 2100 with historical consumption from 1860 to 1998

\begin{tabular}{|c|c|c|c|c|c|c|c|c|}
\hline & \multirow{3}{*}{$\begin{array}{l}\text { Conventional } \\
\text { reserves and } \\
\text { resources } \\
\\
\text { I,II,III }\end{array}$} & \multicolumn{3}{|c|}{ Unconventional } & \multicolumn{3}{|c|}{$\begin{array}{l}\text { Unconventional and } \\
\text { additional occurrences }\end{array}$} & \multirow{3}{*}{$\begin{array}{l}\text { Consumption } \\
1860-1998\end{array}$} \\
\hline & & \multirow{2}{*}{$\begin{array}{l}\begin{array}{l}\text { Enhanced } \\
\text { recovery }\end{array} \\
\text { IV }\end{array}$} & \multicolumn{2}{|c|}{ Recoverable } & \multirow[b]{2}{*}{ VII } & \multirow[b]{2}{*}{ VIII } & \multirow[b]{2}{*}{ Total } & \\
\hline & & & V & VI & & & & \\
\hline Oil & 12.4 & 5.8 & 1.9 & 14.1 & 24.6 & 35.2 & 94 & 5.1 \\
\hline \multirow[t]{3}{*}{ Gas } & 16.5 & 2.3 & 5.8 & 10.8 & 16.2 & 785.4 & 837.1 & 2.4 \\
\hline & \multicolumn{6}{|c|}{ Scenario assumptions } & \multicolumn{2}{|c|}{ Scenario result $1990-2100$} \\
\hline & I,II,III & IV & V & VI & VII & VIII & Oil & Gas \\
\hline $\mathrm{B} 1-\mathrm{H}_{2}$ & Gas/oil & Gas/oil & Gas & Gas & - & - & 16.6 & 24.2 \\
\hline
\end{tabular}

For non-fossil resources, like uranium and renewable energy, future resource potentials are primarily a function of the assumed rates of technological change, energy prices, and other factors such as safety and risk considerations for nuclear power generation.

\subsection{The development of primary energy}

Fig. 3 illustrates the projected changes in the global primary-energy structure over time. ${ }^{3}$ The historical changes reflect major technology shifts, from traditional use of renewable energy flows to the coal and steam age of the 19 th century to the dominance of oil along the 20 th century and the later emergence of natural gas.

The B1- $\mathrm{H}_{2}$ scenario illustrates a relatively smooth transition toward a post-fossil global energy system. Fossil fuels still dominate the primary energy supply until 2050 , but during this period, the system shifts away from coal and oil, which reduce their shares substantially, toward natural gas. The latter operates as the main transitional fuel to the post-fossil era, which unfolds in the second half of the 21st century. During this period, remarkable structural changes become evident. Global primary energy consumption peaks at around $900 \mathrm{EJ}$ in 2070 and declines afterwards. Renewable energy sources, in particular biomass, increase their shares substantially. A transition to a decentralized energy system takes place.

\footnotetext{
${ }^{3}$ In this paper, we adopt the direct equivalent method as primary energy accounting methodology for all non-thermal uses of renewables and nuclear. Using this method, for instance, the primary energy equivalence of electricity generated from solar photovoltaics or nuclear power plants is set equal to their respective gross electricity output.
}

An intensive decarbonization of the energy supply accompanies these transformations. $\mathrm{CO}_{2}$ emissions peak at about 10.5 gigatons of carbon $(\mathrm{GtC})$ in 2040 and reach $5.7 \mathrm{GtC}$ in 2100 , a lower value than in 1990. Fig. 4 presents the evolution of the carbon intensity of the global primary energy supply for the 20th century and the trend in the $\mathrm{B} 1-\mathrm{H}_{2}$ scenario for the 21 st century. The historical development from 1900 to 1990 shows a persistent but slow decarbonization trend of the world's energy system at approximately 0.3 percent per year [23]. In $\mathrm{B} 1-\mathrm{H}_{2}$ the decarbonization trend is substantially accelerated. Between the years 1990 and 2100 , the carbon intensity of global primary energy is reduced at an annual average rate of 0.8 percent per year, as the energy system becomes increasingly non-fossil based.

In $\mathrm{B} 1-\mathrm{H}_{2}$, the combination of a number of technical and societal structural changes, associated with substantial efficiency improvements at the end-use-energy level, leads to a relatively moderate increase of final energy demands during the first half of the 21 st century and to a decline during the second half of the century. This pattern is reflected in corresponding trends in the production of different energy carriers (hydrogen among them) and primary energy consumption. With a fast economic growth and significant structural changes in the energy system, a strong decoupling between economic activity and energy consumption takes place in the 21 st century. Primary energy intensity, i.e. the amount of primary energy used per unit of GDP, is substantially reduced, reflecting the substantial technical progress assumed to prevail in the B1- $\mathrm{H}_{2}$ scenario, at approximately 1.8 percent per annum, well below the historical trend.

\subsection{Global and world regional strategies for hydrogen production}

At the global level, hydrogen is produced with a diversified mix of technologies (see Fig. 5). Steam reforming 


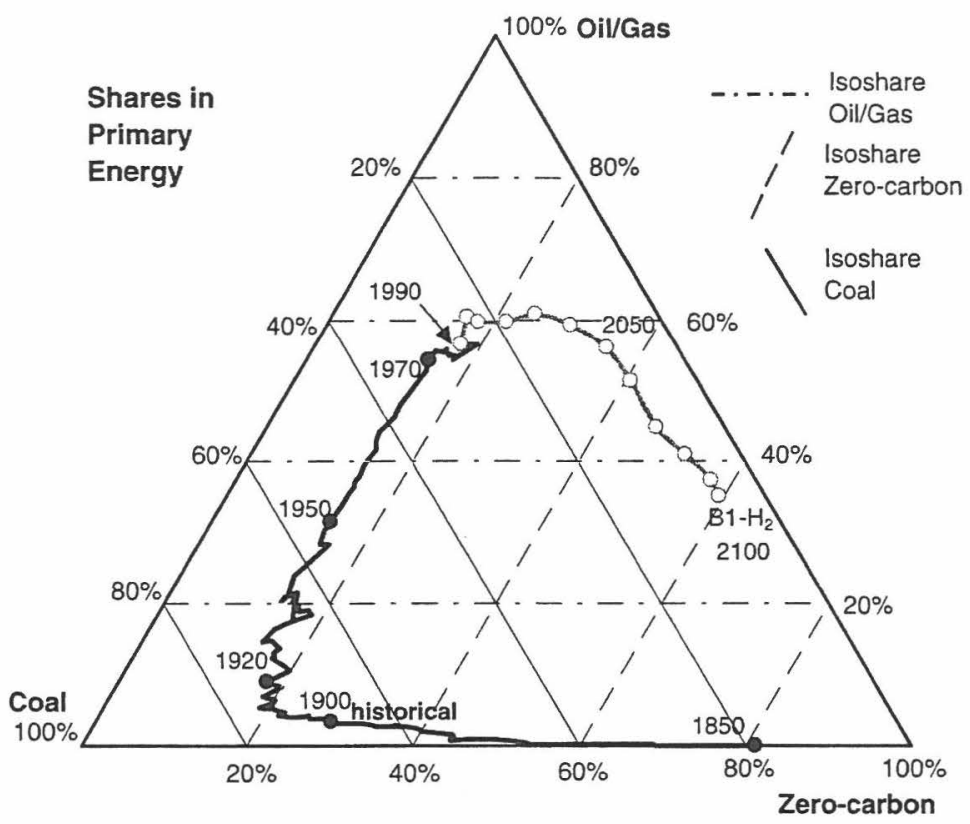

Fig. 3. Global shares in primary energy use, coal, oil/gas, and non-fossil energy, illustrated with an "energy triangle" (in percent). Constant market shares of coal, oil/gas, and non-fossil (carbon-free) energies are denoted by their respective isoshare lines. Data from 1850 to 1990 (black) are based on [22]. The development of the primary energy structure for the $\mathrm{B} 1-\mathrm{H}_{2}$ scenario is shown for the years 1990-2100 (ten-year time steps).

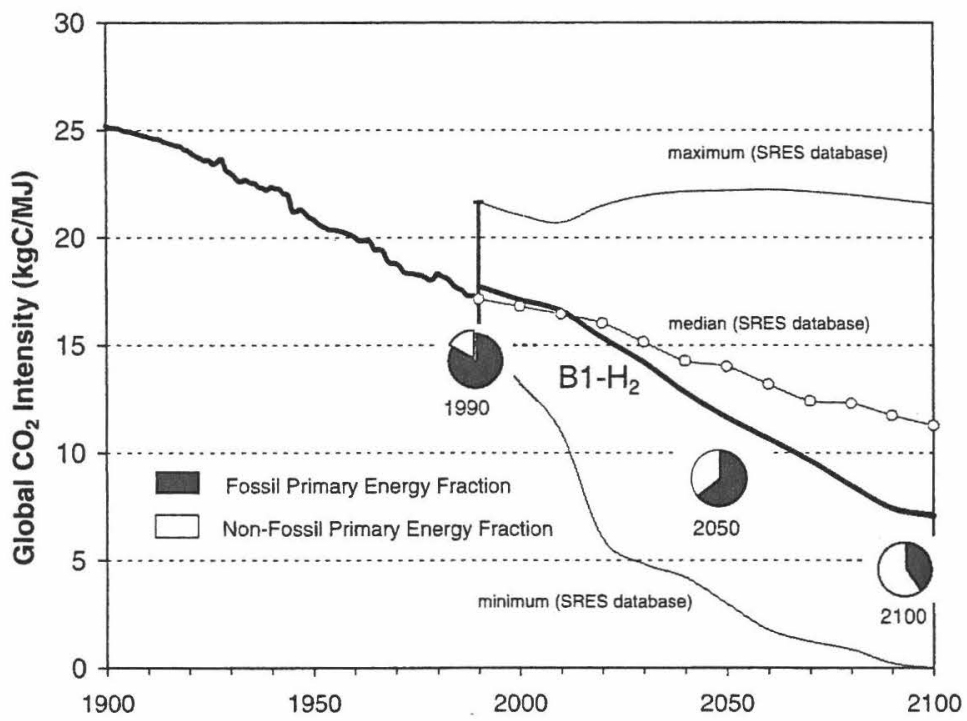

Fig. 4. Decarbonization trend (carbon intensity reduction) of global primary energy supply. Actual development from 1900 to 1990 and in the B1- $\mathrm{H}_{2}$ scenario from 1990 to 2100 . Historical data: [23]; Database: [24].

of natural gas and gasification of biomass play the leading roles. Along the most part of the time horizon, steam reforming holds the largest share of supply. In the last decades of the 21 st century, however, the rapidly increasing production from biomass becomes the most important sup- ply source at the global scale. Significant contributions are also made by the solar thermal technology and, to a lower extent, by coal gasification. The latter operates as a transition technology. Nuclear high-temperature reactors and electrolysis play marginal roles. Still, they constitute valuable 


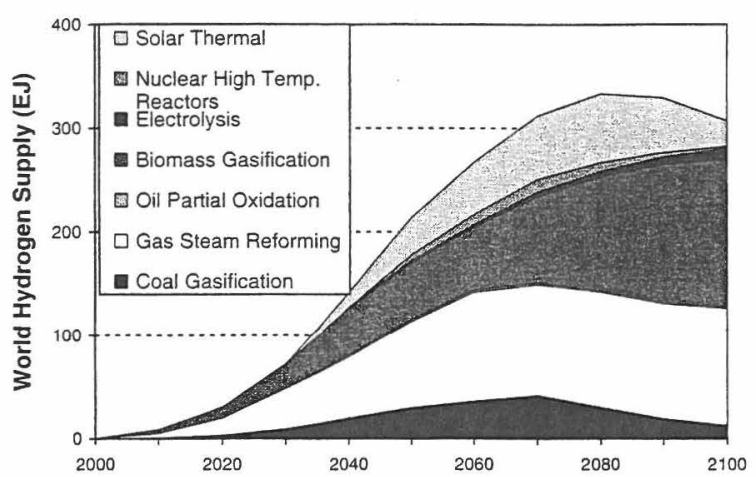

Fig. 5. Global hydrogen supply mix in the $\mathrm{Bl}-\mathrm{H}_{2}$ scenario. Steam reforming of natural gas and gasification of biomass are the dominant technologies.

complementary options in particular niche markets. Following considerable economic and technological structural changes and substantial energy efficient improvements, global hydrogen production peaks at $330 \mathrm{EJ} / \mathrm{yr}$ around the year 2080 and declines afterwards.

As illustrated by the hydrogen production system resulting in this scenario, natural gas could have a crucial role in enabling the successful penetration of hydrogen. Gas is the cleanest hydrocarbon fuel and an abundant resource, which appears as one of the most promising alternatives to provide for clean energy services well into the 21 st century [25]. The development of associated infrastructures and technologies could bring the energy system into an "energy gases era". Hydrogen, also a gaseous fuel, would fit well into a natural gas-dominated energy system. It can be produced from gas and could profit from its transportation and distribution infrastructures.

Steam reforming of natural gas is currently the most widely applied and least expensive method for hydrogen production and could be key in stimulating the penetration of hydrogen into the marketplace, paving the way for the introduction of renewable hydrogen systems. A gas-based hydrogen production system would benefit from the dynamic build-up of gas production and transportation infrastructures and the development of a cluster of advanced methane-based technologies and could be a bridge to a post-fossil hydrogen production system [6].

Developing highly efficient and cost-effective small-scale steam reforming technologies that can be applied in distributed production sites could be the key to overcome some of the barriers imposed by the lack of a large-scale hydrogen delivery infrastructure [7]. Decentralized small-scale reforming of natural gas would produce hydrogen close to the point of use, while profiting from existing natural gas distribution systems. Where inexpensive off-peak electricity is available, electrolyzers could play a similar role, benefiting from the existing power distribution network. Eventually, as the demand for hydrogen grows, centralized large-scale pro- duction plants, which, among others, could facilitate carbon capture and sequestration, may enter the market and a hydrogen transportation and distribution infrastructure could develop.

Renewable resources, specifically biomass and solar energy, also make a very significant contribution to hydrogen production in this scenario. Conversion of biomass into modern energy carriers becomes very significant in the long term in the sustainability-conscious B1- $\mathrm{H}_{2}$ world. Hydrogen production is no exception. Significant cost and performance improvements make biomass gasification emerge as one of the most attractive methods for hydrogen production in the long term, particularly in the developing regions (see Fig. 6). The technology also makes sizeable inroads in the developed regions. Of course, the successful application of biomass technologies for hydrogen production presupposes finding solutions to a number of issues that currently prevent biomass from having a more relevant role in meeting energy needs and have to be dealt with for biomass to be produced in a sustainable way (see e.g. [26]).

Solar thermal hydrogen production systems also make a sizeable contribution in this scenario. At the global level, its contribution peaks at 20 percent in 2080 and declines afterwards to 8 percent at the end of the 21 st century. At the regional level, it has an important contribution in the developing regions. The long-term potential for producing hydrogen from solar energy is enormous and hydrogen represents a convenient medium to overcome the problems posed by the intermittence of this source. Solar hydrogen provides an adequate, less land-intensive, complement to biomass-based systems, which could definitely constitute one of the pillars of a long-term sustainable hydrogen production system.

Since renewable-based technologies offer significant environmental advantages, coal gasification does not become a significant hydrogen production alternative in this scenario. Still, it plays a transitional role in developing regions endowed with significant coal resources, in particular ASIA. For those regions, conversion of coal to hydrogen already represents an important advance toward better quality fuels. On the one hand, the gasification process has the potential to achieve high operating efficiencies and has near-zero emissions of sulfur, nitrogen oxides and particulates and, on the other hand, using hydrogen at the final energy level offers significant advantages over the direct utilization of coal.

This, of course, does not exclude other renewable-based technologies from playing a role in a sustainable "hydrogen economy" in the long-term future. On the contrary, ours is but one example of how such a system could develop. Many different sustainable hydrogen-based energy systems could be possible and might have chances to unfold in the uncertain future. It becomes necessary to quantify the long-term characteristics of those possible alternative energy systems.

In particular, wind or solar photovoltaic-based systems could also play a role in a renewable-based hydrogen production system in the long term. However, as of today, photovoltaic-based (or wind-based) water electrolysis is 

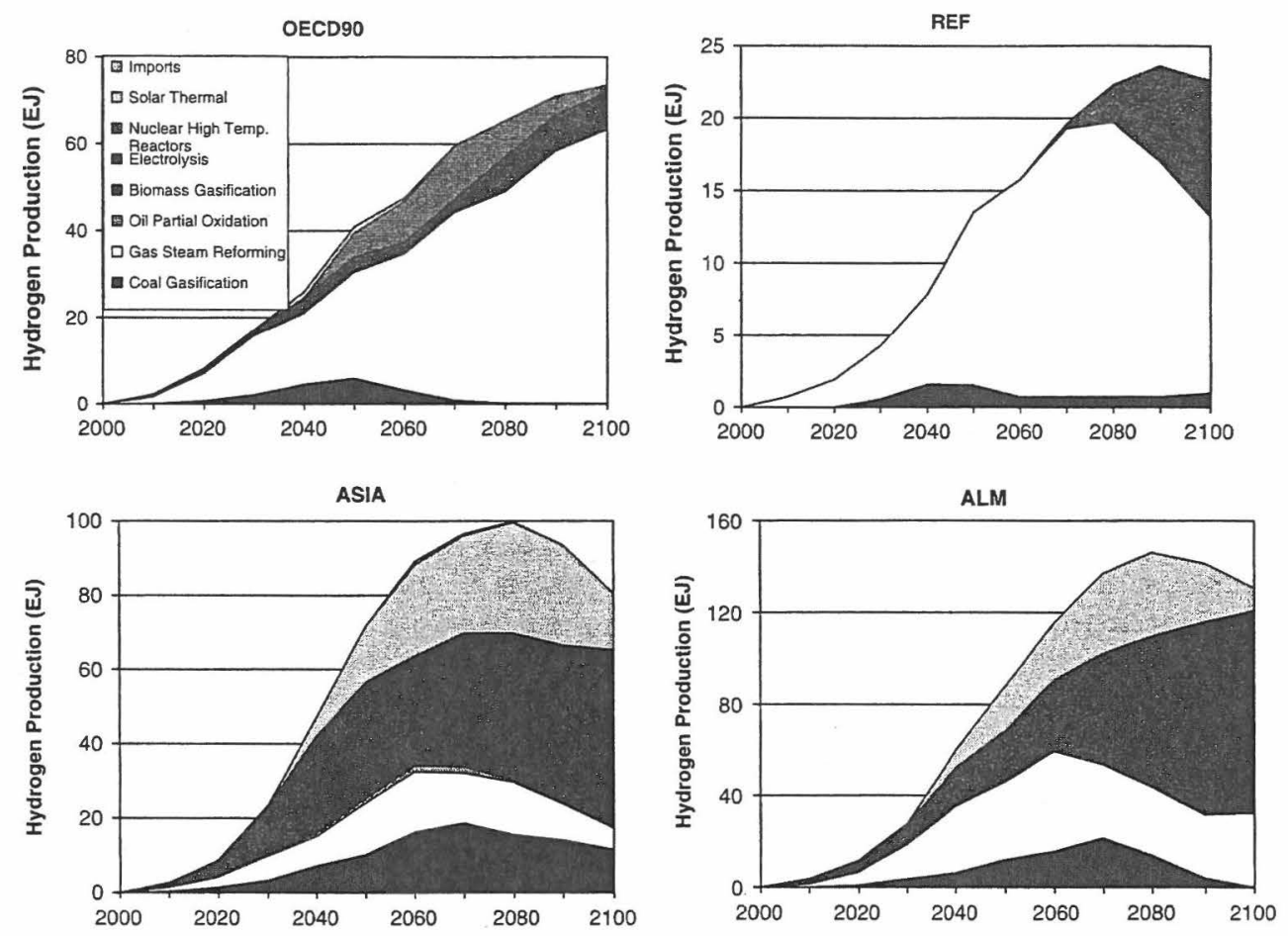

Fig. 6. Hydrogen production mix in the four global macro-regions in the $\mathrm{B} 1-\mathrm{H}_{2}$ scenario.

still one of the most expensive hydrogen production systems [3], among other factors because of the electricity costs. That being said, it must be recognized that wind turbines and solar photovoltaic systems have experienced a substantial progress along their learning curves (see e.g. $[27,28]$ ) and they still have potential to develop further. In addition, some promising advances in electrolyzers are being made. Specifically, compact proton-exchange-membrane (PEM) electrolyzers may offer attractive possibilities (see e.g. [29]) and could fit well in a distributed energy system such as the one portrayed here. Moreover, PEM electrolyzers could benefit from technological learning spillovers from the development of PEM fuel cells. ${ }^{4}$

Regarding this and other alternatives, it must be stated that long-term future technological developments are highly uncertain and the outcome of technological change processes, in particular, the emergence of radical innovations, are difficult to predict. Therefore, the possibility of breakthroughs on innovative technologies that could change sub-

\footnotetext{
${ }^{4}$ Technological learning plays an important role in achieving the cost reductions and performance improvements necessary for a technology to become competitive in the marketplace [30]. Although difficult to quantify, spillovers of technological learning between different technologies can occur [31]. Related or complementary technologies could benefit from the learning processes of each other. This "technological proximity" may stimulate a collective learning and co-evolution process.
}

stantially the panorama of hydrogen production in the future cannot be ruled out.

We turn now to the structure of the regional hydrogen supply systems. In all regions, hydrogen becomes an important energy carrier and a corresponding production infrastructure is developed. The structure of the regional hydrogen production systems very much reflects the resources (indigenous or imported) available in each region (see Fig. 6).

The industrialized regions (OECD90 and REF) rely heavily on steam reforming of natural gas for the hydrogen supply. In the OECD90, natural gas, part of which is imported from the REF region, accounts for the bulk of hydrogen production. Nuclear high-temperature reactors and biomass gasification are also applied, but their share begins to be noticeable only in the second half of the century. A small transitional contribution comes from coal gasification. In the case of REF, indigenous gas resources provide the largest part of $\mathrm{H}_{2}$ production although, toward the end of the century, an increasing share of biomass gasification becomes noticeable. Coal gasification holds also a small share of the production along the time horizon.

The developing regions show a more diversified pattern, with less reliance on natural gas. Biomass gasification and solar thermal plants have the highest contributions to the long-term supply. By the end of the 21st century, biomass gasification becomes the dominant option in those regions accounting for 53 percent of hydrogen production in ASIA 
and 64 percent in the ALM region. As mentioned before, solar thermal hydrogen production systems also make an important contribution. Peak shares of 30 and 25 percent are reached in 2080 in ASIA and ALM respectively.

Coal gasification and steam reforming, however, still have a considerable participation, although mainly in the first half of the century. Coal-based hydrogen is particularly important in ASIA, where countries such as China and India lack significant gas resources. Coal-based systems still provide approximately 15 percent of the total hydrogen production of the region at the end of the 21 st century. In contrast, in the ALM region, where ample gas resources are available, the steam reforming technology provides a more significant contribution. It holds 40 percent of the total production in the year 2050 but its share declines to 25 percent at the end of the 21 st century as renewable sources become dominant. Coal gasification plays a more reduced role in the ALM region, strongly declining its participation in the hydrogen-supply mix toward the end of the 21st century.

No significant amounts of hydrogen are traded across world regions in this scenario. Hydrogen pipelines were not considered and transporting liquefied hydrogen in ships does not become cost effective. In addition, although the injection of small fractions (up to $10 \%$ on a volume basis) of hydrogen into the natural gas pipelines is possible, no significant amounts are transported this way. Thus, hydrogen is made where it is required, close to the demand centers and mainly using indigenous resources. Still, hydrogen production has some noticeable impact on the international trade of natural gas. Specifically, Western Europe imports significant amounts of gas from the Former Soviet Union that is used as a feedstock for its hydrogen production. Our result is consistent with current and foreseeable cost trends that indicate that several of the feedstocks used to produce hydrogen can be transported over long distances cheaper than hydrogen itself [3].

This dispersed $\mathrm{H}_{2}$ supply brings tangible benefits in terms of security of supply for a number of regions. Without excessive reliance on imported feedstocks or dependence on long-distance transportation infrastructures, such $\mathrm{H}_{2}$ production infrastructure contributes to cast a better geographical balance of energy resources and reduce vulnerability to geopolitical uncertainties and security risks.

In summary, the regional hydrogen supply systems in the B1- $\mathrm{H}_{2}$ scenario evolve in a diversified way according to the resources at hand. In industrialized regions, hydrogen production remains mainly fossil based, with steam reforming of natural gas as the dominant technology. Still, other options, biomass gasification in particular, also make sizeable contributions. In the developing regions, on the other hand, although fossil-based production technologies, i.e. steam reforming of natural gas and coal gasification, play an important role, the system evolves much more rapidly to a predominantly renewable-based structure, relying on biomass gasification and solar thermal plants.

\subsection{Electricity generation and the role of fuel cells}

In the $\mathrm{B} 1-\mathrm{H}_{2}$ scenario, electricity production strongly shifts away from traditional centralized fossil-based technologies toward post-fossil and zero-carbon generation systems. Such transition contributes substantially to achieve sustainable-development goals in the electricity system. By the end of the 21 st century, hydrogen-based fuel cells, renewables and nuclear power plants become the leading suppliers, while coal and oil power plants are completely phased out. The only fossil fuel that remains is natural gas and its share is small compared to other options. However, natural gas power plants, more specifically the gas-fired combined cycle, play an important role "bridging" the long-term transition to advanced post-fossil systems. Fig. 7 presents the market shares of generation technologies in the global electricity mix for the years 2020, 2050 and 2100 .

The transformation of the global electricity sector is substantial, not only regarding primary fuels, but also regarding its very nature. Large-scale centralized power plants give way to small-scale distributed generation systems that operate nearer the point of use. A substantial amount of highly efficient, cost-effective and less vulnerable micropower systems penetrates the global electricity markets at a quick pace, driven by technological breakthroughs and accompanied by a favorable institutional and regulatory revolution.

With increasing production volume, micropower technologies progress rapidly along their learning curves, experiencing significant cost reductions and performance improvements. This, together with additional benefits on reliability, reduced environmental impacts, shorter times to market, averting transmission and distribution costs, flexibility, etc., contribute to make them the preferred options [32]. Parallel to their penetration, advanced communications, control and metering technologies are developed and applied in "intelligent" electrical grids, allowing the flexible and reliable operation of the distributed power generation system.

By the end of the 21 st century, decentralized systems, mainly hydrogen-based fuel cells and on-site solar photovoltaics installations, hold almost a 50 percent share of the global electricity market. Fuel cells, in particular, experience a dramatic growth. Electricity co-generation in industrial and residential stationary fuel-cell applications and generation from mobile hydrogen-based fuel cells in the transportation sector (e.g. fuel-cell-powered cars generating electricity while parked) become major contributors to the generation mix, accounting for approximately 38 percent of the global generation market in 2100 .

In this scenario, hydrogen-based fuel cells play a major role while fuel cells powered by fossil fuels, such as natural gas or coal, only have a minor contribution (see Fig. 7). Hydrogen-based fuel cells do not emit carbon at the point of generation, but the hydrogen production system can still be responsible for carbon emissions if fossil fuels are used as feedstocks. However, the increasing renewable share 


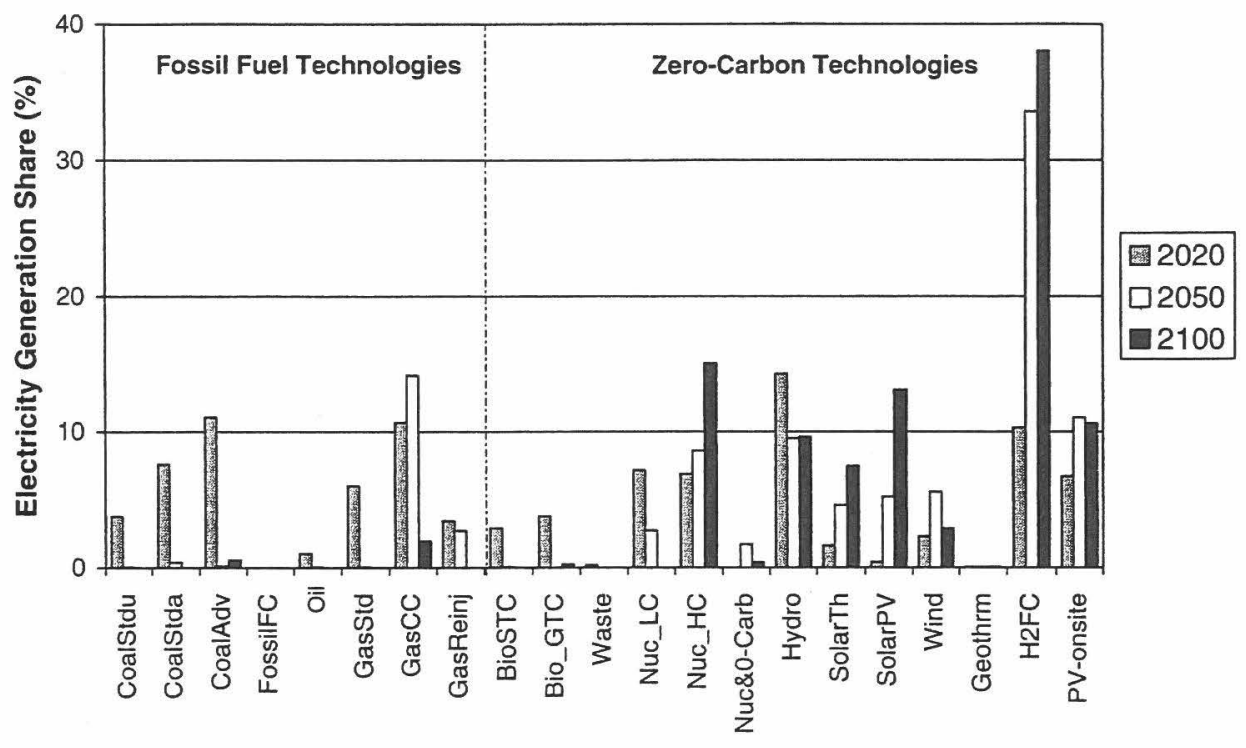

Fig. 7. World market shares for aggregate electricity generation technologies in the years 2020,2050 and 2100 in the B1- $\mathrm{H}_{2}$ scenario. Abbreviations used to indicate the aggregate technologies are explained in the appendix. It must be noticed that, although hydrogen fuel cells $(\mathrm{H} 2 \mathrm{FC})$ are shown here within the group of zero-carbon technologies, they only become a true zero-carbon option when the hydrogen production system becomes non-fossil based.

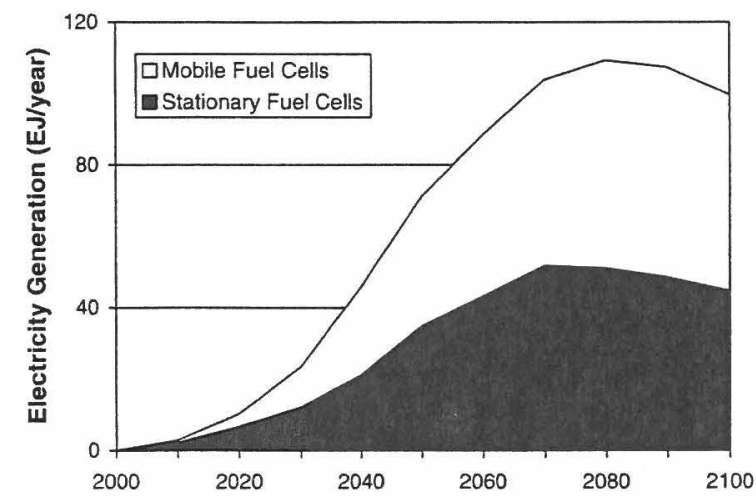

Fig. 8. Global electricity generation from hydrogen-based fuel cells in the $\mathrm{B} 1-\mathrm{H}_{2}$ scenario. Contributions of electricity production from mobile fuel cells in the transportation sector (top) and co-generation from stationary fuel cells in residential/commercial and industrial applications (bottom) are distinguished.

in the hydrogen production system makes hydrogen-based fuel cells important components in the transition toward a zero-emission electricity system.

Fig. 8 depicts the global electricity generation from hydrogen fuel cells distinguishing between the contributions of stationary co-generation facilities in residential/commercial and industrial applications and off-peak electricity generation from fuel cells in the transportation sector. Global generation from fuel cells peaks at $110 \mathrm{EJ} / \mathrm{yr}$ in the year 2080 and experiences some decline afterwards. As mentioned be- fore, such a decrease is in line with the lower consumption of final energy carriers resulting from the high efficiency improvements at the end-use level assumed in this scenario. However, as shown above, the fraction of the global market captured by fuel cells continues to grow steadily along the 21 st century.

Both stationary co-generation facilities and electricity production from mobile sources play important roles. Initially, the contribution of stationary applications is larger but, as technological, institutional and regulatory developments unfold, mobile sources of power are able to increase their electricity output. This parallel growth allows synergies between both market segments facilitating both the fuel cells production volumes build-up and the deployment of hydrogen production and delivery systems.

\subsection{Hydrogen as the main final energy carrier}

During the course of the 21 st century, the final energy mix of the $\mathrm{B} 1-\mathrm{H}_{2}$ scenario changes considerably, as the trend toward cleaner, more flexible and convenient energy carriers continues (see Fig. 9).

Solid fuels, such as coal and biomass, are gradually phased out of the final energy market. Oil products, today's prevailing fuels, reduce their share drastically. Grid-delivered energy carriers as electricity and hydrogen increasingly dominate the final-energy mix. Hydrogen, in particular, driven by the penetration of efficient end-use technologies, increases its share dramatically, accounting for approximately 49 percent of the global final consump- 


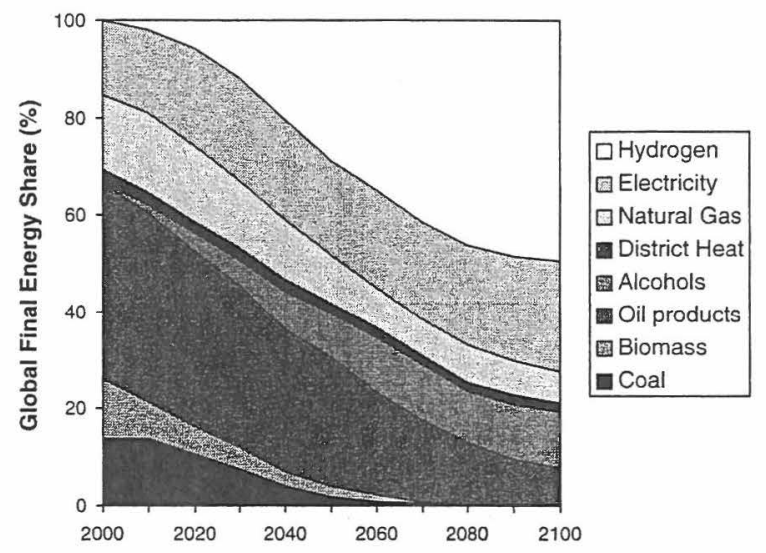

Fig. 9. Evolution of global market shares of different final-energy carriers for the period $1990-2100$ in the $\mathrm{B} 1-\mathrm{H}_{2}$ scenario. The alcohols category includes methanol and ethanol.

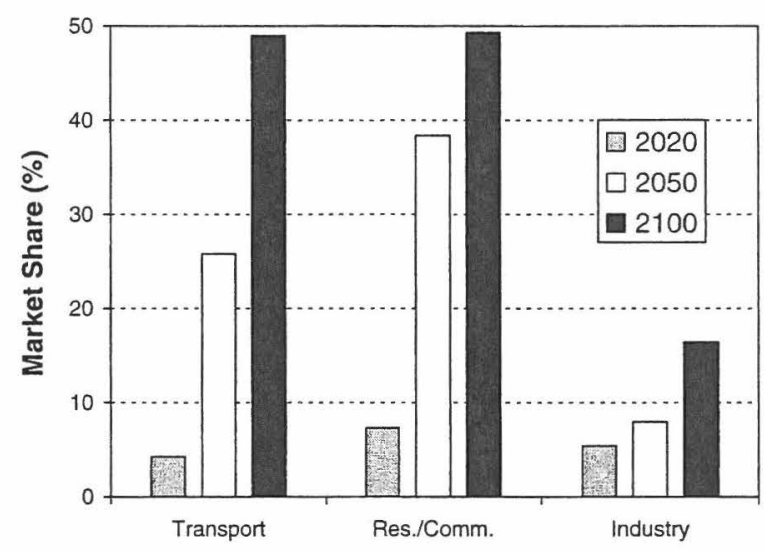

Fig. 10. Global shares of hydrogen in the final-energy mix of the transportation, residential/commercial and industrial sectors for the years 2020,2050 and 2100 in the $\mathrm{B} 1-\mathrm{H}_{2}$ scenario.

tion by the end of the 21 st century, and becomes the main final energy carrier.

With intensified R\& D efforts and setting in motion sound deployment strategies, substantial but achievable performance improvements and cost reductions occur in hydrogen-based technologies and they diffuse widely. Hydrogen technologies are introduced in a variety of applications across all end-use sectors, being particularly successful in mobile applications in the transportation sector and in stationary co-generation applications in the residential/commercial sector.

Fig. 10 illustrates the global market shares of hydrogen in the final-energy mix of the industrial, residential/commercial and transportation sectors for the years 2020, 2050 and 2100 .

In this scenario, a "revolution" takes place in the transportation sector, as the dependence on oil products is strongly reduced. The severe burden imposed by transporta-

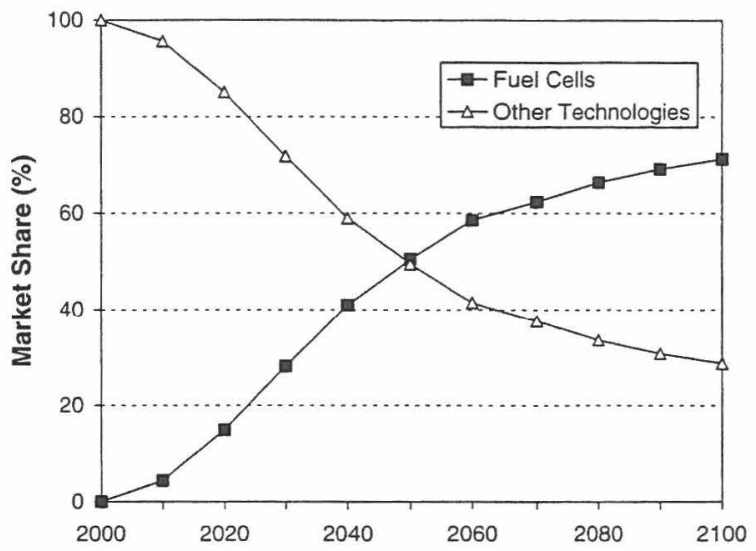

Fig. 11. Evolution of the market share of fuel cells versus the aggregate of other technologies in the global transportation sector in the $\mathrm{B} 1-\mathrm{H}_{2}$ scenario.

tion activities on the environment at the local, regional and global levels and the growing share of its energy consumption make the move to a sustainable transportation system a priority target. Alternative fuels such as hydrogen, methanol (made of fossil sources, primarily natural gas) and ethanol (synthesized from biomass) capture significant shares of the market displacing oil products. By 2050, hydrogen accounts for already 25 percent of the global final-energy consumption in the transportation sector and by the end of the 21 st century its share will have risen to 50 percent.

Fuel cells drive forward this transformation. Being either directly fueled by hydrogen, or by ethanol or methanol combined with an on-board fuel processor to obtain the hydrogen required, fuel cells penetrate extensively the transportation markets, displacing currently dominating technologies such as the internal combustion engine. Fig. 11 presents the evolution of the market share of fuel cells versus the aggregate of other technologies in the global transportation sector during the 21 st century in our scenario. The aggregate share of fuel cells is already 51 percent in the year 2050 and rises to 71 percent in 2100 . The main role is played by hydrogen-based fuel cells, but alcohol-based fuel cells operate as important complementary options.

Penetration of hydrogen in the residential/commercial markets is also substantial, as fuel cell co-generation of electricity and heat becomes an attractive option. Driven by the penetration of stationary fuel cells appropriately scaled to the buildings' needs, hydrogen reaches 38 percent of the final-energy consumption of the residential/commercial sector in the year 2050 and accounts for almost 50 percent at the end of the 21 st century. Its penetration is much lower in the industrial sector where many applications can be effectively served directly by electricity. Still, with fuel cell co-generation providing energy services to important industrial niche markets, hydrogen captures 8 percent of the final-energy mix of this sector in the year 2050. This share increases to 17 percent in 2100 . 


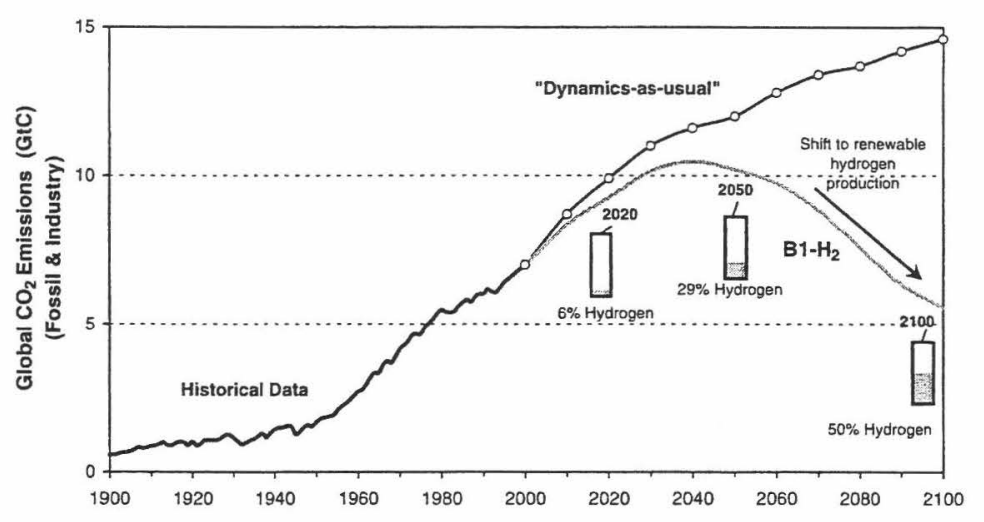

Fig. 12. Carbon emissions in the $\mathrm{B} 1-\mathrm{H}_{2}$ scenario (gray) compared to the emissions for a dynamics-as-usual development (black, white circles), and actual development from 1900 to 2000 .

From today's perspective, if penetration of hydrogen and fuel cells is to be successful, opportunities in different sectors must be tapped. Transportation constitutes indeed a primary target market for both fuel cells and hydrogen. Market potential is huge and benefits can be very significant. Among others, fuel cell vehicles could contribute significantly to curb air pollution, increase energy efficiency and reduce dependence on fossil fuels and could be favored by specific policies to introduce low-emission vehicles. However, barriers for the penetration, ranging from supply infrastructures to onboard storage problems and perceived safety risks, appear to be high. Other market segments, where barriers are less severe, may offer attractive opportunities to stimulate early introduction. Potential synergies between, for instance, the buildings and vehicles markets could be used to make hydrogen a more attractive alternative and help to overcome the initial infrastructure barrier [7].

This calls for a coordinated strategy for the deployment of hydrogen technologies in different market segments, in order to profit from potential synergies and benefit from the cost reductions as the volume of manufacturing and sales builds up. R\& D, demonstration and commercialization strategies must be targeted at overcoming the barriers specific to each market segment while exploiting the advantages of hydrogen [33].

\subsection{Hydrogen and global warming}

This section describes the global environmental consequences of the carbon concentration and emission trajectory derived from the quantification of the $\mathrm{B} 1-\mathrm{H}_{2}$ scenario. In order to provide an adequate perspective, we will compare the climate impacts of $\mathrm{B} 1-\mathrm{H}_{2}$ with a scenario where the long-term patterns of change are guided by "dynamics-as-usual" trends. Generally, "dynamics-as-usual" scenarios assume that rates of change for the main scenario drivers, such as technological enhancement, demographic changes, and economic development follow historical experience. Hence, they tend to result in relatively high levels of GHG emissions and climate impacts [34]. Standard indicators of climate impacts are radiative forcing and global mean temperature change [35]. Using these indicators, and considering the uncertainty associated with them, we will explore to which extent the introduction of hydrogen mitigates global impacts of climate change.

To estimate possible global climate effects of the B1- $\mathrm{H}_{2}$ scenario, the climate model MAGICC (version 2.3) was used [36]. For the $\mathrm{B} 1-\mathrm{H}_{2}$ scenario, we estimated the direct and indirect $\mathrm{GHG}$ emissions including $\mathrm{CO}_{2}, \mathrm{CH}_{4}, \mathrm{~N}_{2} \mathrm{O}, \mathrm{SO}_{2}, \mathrm{CFC} / \mathrm{HFC} / \mathrm{HCFC}, \mathrm{PFC}, \mathrm{SF}_{6}, \mathrm{CO}$, VOCs and $\mathrm{NO}_{x}$. Non-energy-sector emissions were estimated using corresponding land-use change model runs with equivalent input assumptions based on the IPCC-B1 scenario developed with the AIM model [37]. Halocarbon emissions are based on estimates for the SRES-B1 scenario by Fenhann [38]. In this section, we will mainly focus on $\mathrm{CO}_{2}$ emissions and concentrations, today's main contributors to global warming [39].

The $\mathrm{CO}_{2}$ emissions resulting in the $\mathrm{B} 1-\mathrm{H}_{2}$ scenario are compared to a dynamics-as-usual case in Fig. 12. As the dynamics-as-usual scenario, we selected the IIASA B2 marker scenario developed for the IPCC-SRES [11]. For details on the B2 scenario, see [34].

In B2, global carbon emissions from energy use and industrial sources rise from $6.2 \mathrm{GtC}$ in 1990 to $14.2 \mathrm{GtC}$ in 2100 . In contrast, due to the rapid introduction of bydrogen technologies, $\mathrm{CO}_{2}$ emissions from energy and industrial sources in the $\mathrm{B} 1-\mathrm{H}_{2}$ scenario are considerably lower. The initial raise of $\mathrm{CO}_{2}$ emissions in $\mathrm{B} 1-\mathrm{H}_{2}$ along the first half of the 21 st century is mainly a result of the growth of energy demand. During this period, however, hydrogen infrastructures develop and become progressively more important in decarbonizing the energy system. Emissions peak around $10.5 \mathrm{GtC}$ in 2040 and decrease later below 1990 emissions in 2100 ( $5.7 \mathrm{GtC})$, when hydrogen production shifts toward renewable sources (see Fig. 12). 


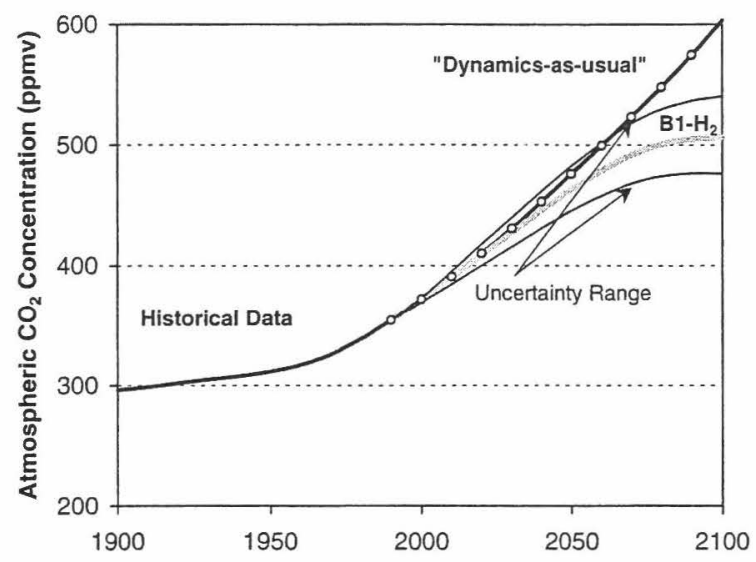

Fig. 13. Atmospheric $\mathrm{CO}_{2}$ concentrations. Historical development from 1900 to 1990 and future trajectories for the $\mathrm{Bl}-\mathrm{H}_{2}$ (gray) and the "dynamics-as-usual" (black, white circles) scenarios. The thin lines depict the uncertainty range for $\mathrm{B} 1-\mathrm{H}_{2}$ given by the variation of the assumed $\mathrm{CO}_{2}$ fertilization effect.

The resulting atmospheric carbon concentrations of the scenarios are illustrated in Fig. 13. The carbon concentrations climb steadily under dynamics-as-usual assumptions and reach 600 parts per million by volume (ppmv) in 2100 . In contrast, $\mathrm{B} 1-\mathrm{H}_{2}$ depicts a route to stabilizing the concentrations at about 500 ppmv. ${ }^{5}$ As illustrated in Fig. 13, even the upper bound of the uncertainty range for the $\mathrm{B} 1-\mathrm{H}_{2}$ scenario stabilizes at $540 \mathrm{ppmv}$, which is considerably below the best-guess estimate of the dynamics-as-usual scenario.

Fig. 14 illustrates total radiative forcing due to all GHG and aerosol emissions relative to 1990 . In the year 2100 , total radiative forcing differs significantly between $\mathrm{B} 1-\mathrm{H}_{2}$ and the dynamics-as-usual scenario. As with carbon emissions and concentrations, radiative forcing climbs steadily under dynamics-as-usual assumptions and reaches $4.1 \mathrm{~W} / \mathrm{m}^{2}$ in 2100 . In contrast, $\mathrm{B} 1-\mathrm{H}_{2}$ depicts a route to stabilizing forcing at about $3.2 \mathrm{~W} / \mathrm{m}^{2}$. Up to about the year 2070 , however, total radiative forcing is almost identical for the scenarios. This is due to the combined inertia of the energy system and the climate system, and a balancing effect of sulfur emissions. Compared to dynamics-as-usual, the more rapid technological progress in the $\mathrm{B} 1-\mathrm{H}_{2}$ scenario

\footnotetext{
${ }^{5}$ The uncertainty range for the carbon concentrations is due to the present uncertainties associated with net carbon sinks. The uncertainty range of carbon concentrations was calculated with MAGICC by the variation of the 1980 s-mean value of net land-use change $\mathrm{CO}_{2}$ emissions. The $1980 \mathrm{~s}$-mean value approximates the net assumed $\mathrm{CO}_{2}$ fertilization effect, i.e. the biosphere acts as a larger or smaller net carbon "sink" thus resulting, respectively, in lower or higher atmospheric concentrations of $\mathrm{CO}_{2}$. For the best-guess estimates, we assumed $1.1 \mathrm{GtC} / \mathrm{yr}$, which corresponds to the IPCC Second Assessment Report mid-range value [35]. For the uncertainty range, we used the IPCC-defined range of 0.4 and $1.8 \mathrm{GtC} / \mathrm{yr}$.
}

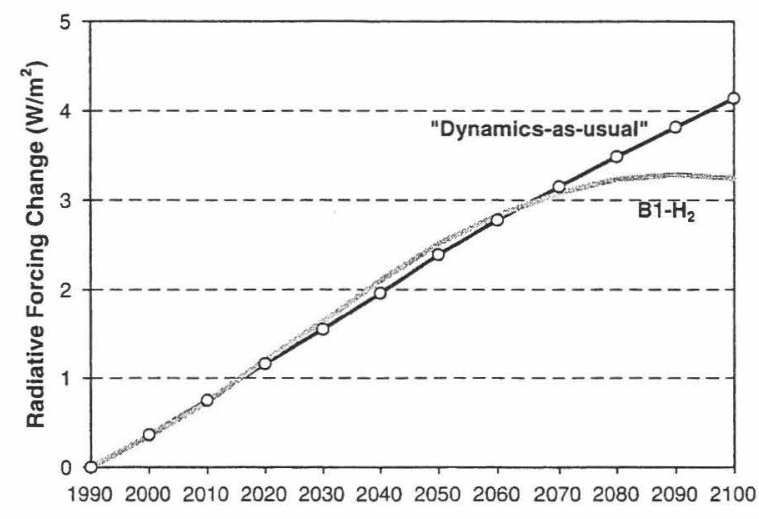

Fig. 14. Global radiative forcing change relative to 1990 for the $\mathrm{B} 1-\mathrm{H}_{2}$ (gray) and the dynamics-as-usual (black, white circles) scenarios.

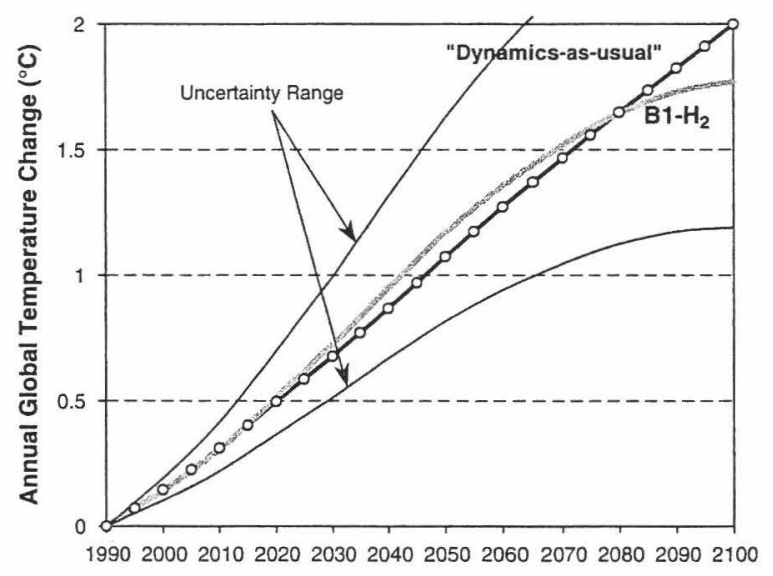

Fig. 15. Global mean temperature change. Future trajectories for the $\mathrm{B} 1-\mathrm{H}_{2}$ (gray) and the "dynamics-as-usual" (black, white circles) scenarios, assuming an intermediate "best guess" climate sensitivity of $2.5^{\circ} \mathrm{C}$ for a doubling of $\mathrm{CO}_{2}$ concentration. The thin lines depict the uncertainty range for $\mathrm{B} 1-\mathrm{H}_{2}$ given by the variation of the climate sensitivity between $1.5^{\circ} \mathrm{C}$ and $4.5^{\circ} \mathrm{C}$.

results in lower $\mathrm{CO}_{2}$, but also lower sulfur emissions. Reduction of sulfur emissions enhances radiative forcing and GHG-induced warming, in contrast to $\mathrm{CO}_{2}$ emissions where radiative forcing is enhanced in line with rising emissions. These two effects counterbalance each other until $\mathrm{CO}_{2}$ emissions start differing substantially in the two scenarios. The radiative forcing until 2060 is slightly higher for the $\mathrm{B} 1-\mathrm{H}_{2}$ as compared to the dynamics-as-usual case (see Fig. 14).

Global mean temperature change (see Fig. 15) shows a similar pattern as radiative forcing. The mean temperature in the dynamics-as-usual case increases steadily and heads upwards in 2100. Meanwhile in B1- $\mathrm{H}_{2}$, temperature starts to level off in the 2070 s to stabilize later at the end of the century. If we use a "best-guess" climate sensitivity of $2.5^{\circ} \mathrm{C}$, we estimate global mean temperature to change until the 
year 2100 by about $1.8^{\circ} \mathrm{C}$ for $\mathrm{B} 1-\mathrm{H}_{2}$ and about $2^{\circ} \mathrm{C}$ for the dynamics-as-usual scenario. ${ }^{6}$ However, the climate sensitivity parameter is highly uncertain, and consequently the uncertainty range for temperature change (calculated by the variation of the climate sensitivity parameter) for $\mathrm{B} 1-\mathrm{H}_{2}$ is vast (see Fig. 15). For the year 2100 , the range is from $1.2^{\circ} \mathrm{C}$ to $2.6^{\circ} \mathrm{C}$. Most interestingly, the corresponding upper bound for $\mathrm{B} 1-\mathrm{H}_{2}$ is much higher than the best-guess estimate for the dynamics-as-usual scenario $\left(2^{\circ} \mathrm{C}\right)$.

The results illustrate that, although the massive introduction of renewable hydrogen succeeds in the long-term decarbonization of the energy system, the actions taken might still not be sufficient to protect against the risk of high climate sensitivities and, hence, high climate impacts. Future policies should therefore focus on the timely development of technologies, which could enable an even more rapid reduction of carbon from the atmosphere than in $\mathrm{B} 1-\mathrm{H}_{2}$. As illustrated in this paper, hydrogen-based technologies could constitute flexible risk management options for the energy system and, thus, would be prime candidates for a hedging strategy against an uncertain climate future.

Our scenario results also highlight another promising alternative that could be part of a portfolio of climate risk management options. In $\mathrm{B} 1-\mathrm{H}_{2}$, biomass gasification is one of the main sources of hydrogen. Besides enabling the production of carbon-neutral energy carriers (if biomass is produced in a sustainable way), biomass-based energy technologies can be combined with carbon capture and sequestration [40]. Doing so could result in additional cumulative emissions reductions of carbon throughout the century, and hence, these technologies could play an important role in limiting climate change risks.

\section{Conclusions}

Hydrogen has an outstanding potential for being a key factor in driving the global energy system to a sustainable trajectory. It can deliver high-quality, highly efficient energy services while contributing to reduce local, regional and global environmental impacts. This paper presents the quantification of the global energy scenario $\mathrm{B} 1-\mathrm{H}_{2}$, which illustrates a long-term transitional path from today's fossil fuel-based energy system toward a clean and sustainable hydrogen future.

B1- $\mathrm{H}_{2}$ presents an affluent, low population growth world driven by equity and sustainability issues, thus providing an adequate framework to analyze the potential contribution

\footnotetext{
${ }^{6}$ The climate sensitivity defines the equilibrium response of global mean surface air temperature to an instantaneous doubling of $\mathrm{CO}_{2}$ or $\mathrm{CO}_{2}$-equivalent concentration. The mid-range estimate of this parameter given in [35] is $2.5^{\circ} \mathrm{C}$, with a range of $1.5-4^{\circ} \mathrm{C}$. These three values for climate sensitivity $\left(1.5^{\circ} \mathrm{C}, 2.5^{\circ} \mathrm{C}\right.$ and $\left.4^{\circ} \mathrm{C}\right)$ define the uncertainty of global temperature change for the $\mathrm{B} 1-\mathrm{H}_{2}$ scenario illustrated in Fig. 15.
}

of hydrogen technologies. In $\mathrm{B} 1-\mathrm{H}_{2}$, hydrogen becomes the main long-term final-energy carrier and corresponding production and distribution infrastructures are developed. Hydrogen-based technologies diffuse rapidly and play a major role in a substantial transformation of the structure of the global energy system. As a result, a more flexible, distributed, less vulnerable and secure system emerges, which meets energy needs in a cleaner, more efficient and cost-effective way.

Fuel cells play a central part in the transformation portrayed by the $\mathrm{B} 1-\mathrm{H}_{2}$ scenario. Being a versatile, clean and flexible technology, fuel cells become a major option in providing transportation services and supplying heat and electricity for a wide range of applications. As they diffuse, fuel cells enable far-reaching changes in those sectors. Specifically, together with other distributed-generation alternatives they contribute substantially to the shift to a more flexible, cleaner and less vulnerable distributed electricity generation system. In addition, they become a strategic component of the transition to a far less polluting and less oil-dependent transportation system.

The production system, initially fossil-based (steam reforming of natural gas), evolves toward renewable resources (solar and biomass) in the long run, contributing to drive the global energy system to a sustainable trajectory. No significant trade of hydrogen occurs but regional hydrogen production systems still have some impact on the trade volumes of other energy carries, specifically natural gas. In general, however, in $\mathrm{B} 1-\mathrm{H}_{2}$ hydrogen is produced close to the demand centers, mainly from indigenously available resources. This dispersed $\mathrm{H}_{2}$ supply brings tangible benefits in terms of security of supply for a number of regions, as it contributes to reduce their reliance on imported energy carriers and their dependence on long-distance transportation infrastructures, thus mitigating the vulnerability to geopolitical uncertainties.

Although in $\mathrm{B} 1-\mathrm{H}_{2}$, the global hydrogen production system progressively shifts toward renewable sources, significant differences subsist in the hydrogen production mix across different regions along the time horizon. Specifically, industrialized regions rely mainly on steam reforming of natural gas to satisfy their hydrogen needs, while developing regions, where a higher demand for hydrogen occurs, rely on a more diversified supply system with a higher share of renewable-based hydrogen production.

This highlights the multiple ways in which a "hydrogen economy" can evolve, depending, among other factors, on the infrastructure available in a particular region. Where gas infrastructures are in place or in development, such as in the developed world, the hydrogen production system could evolve to rely more on natural gas, at least in the medium term. On the other hand, in many developing countries, where much less infrastructure is available and energy demands are likely to grow much faster, the system could move more readily into a renewablebased path. For the latter, however, this would entail the 
Table 2

\begin{tabular}{|c|c|}
\hline Coal Stdu & Aggregation of various types of traditional (single steam cycle) coal power plants without FGD and DENOX \\
\hline Coal Stda & $\begin{array}{l}\text { Aggregation of various types of traditional (single steam cycle) coal power plants with FGD up to } 90 \text { percent and DENOX } \\
\text { up to } 50 \text { percent }\end{array}$ \\
\hline CoalAdv & Integrated (coal) gasification combined cycle with 99 percent FGD and DENOX. Some potential for co-generation \\
\hline Oil & $\begin{array}{l}\text { Aggregation of various types of oil power plants (includes e.g. Rrankine cycle with low } \mathrm{NO}_{x} \text { emissions and } 90 \text { percent } \\
\text { DENOX, but also light oil fueled engine plants). Some potential for co-generation }\end{array}$ \\
\hline GasStd & Standard natural gas power plant (rRankine cycle) with district heat co-generation \\
\hline $\mathrm{GasCC}$ & Natural gas combined cycle power plant including some potential for co-generation \\
\hline GasReinj & $\begin{array}{l}\text { Natural gas combined cycle power plant with zero carbon emissions } \mathrm{CO}_{2} \text { is assumed to be re-injected in gas or oil fields } \\
\text { (e.g. for enhanced recovery). Efficiency loss due to re-injection (compared to GCC) about } 1 \text { percent }\end{array}$ \\
\hline Fossil FC & $\begin{array}{l}\text { Coal- and gas-based high-temperature fuel cell. It is assumed in most of the scenarios that this technology will be available } \\
\text { commercially after } 2010\end{array}$ \\
\hline Waste & Standard municipal waste power plant (rRankine cycle) with 90 percent FGD and 50 percent DENOX \\
\hline BioSTC & Biomass power plant (single steam cycle) with some potential for district heat co-generation \\
\hline Bio_GTC & Biomass gasification power plant \\
\hline Nuc $\perp C$ & Low-cost conventional nuclear power plant (light and heavy water reactor) \\
\hline Nuc_HC & High-cost conventional nuclear power plant (light and heavy water reactor) \\
\hline Nuc\& 0_carb & $\begin{array}{l}\text { Aggregation of various types of advanced nuclear power plants including high-temperature and fast breeder reactors with } \\
\text { some potential for district heat and hydrogen co-generation }\end{array}$ \\
\hline Hydro & $\begin{array}{l}\text { Aggregation of various types of hydroelectric power plants. Low- and high-cost plants are distinguished in all scenarios } \\
\text { in order to reflect the influence of different sites and other factors on the plant costs }\end{array}$ \\
\hline SolarTh & Solar thermal power plant with storage and some potential for district heat and hydrogen co-generation \\
\hline SolarPV & Solar photovoltaic power generation excluding onsite electricity production (predominantly large-scale power plants) \\
\hline Wind & Wind turbine power plant \\
\hline Geothrm & Geothermal power plant \\
\hline $\mathrm{H} 2 \mathrm{FC}$ & $\begin{array}{l}\text { Aggregation of types of hydrogen fuel cells for industrial and residential use with some potential for district heat } \\
\text { co-generation }\end{array}$ \\
\hline PV-onsite & Photovoltaic onsite electricity production \\
\hline
\end{tabular}

ability of "leap-frogging" [41]. That is, avoiding the development of large-scale fossil-based energy systems and associated long-lived infrastructures and moving directly to new, cleaner and more efficient energy technologies and infrastructures. Such a "leap-frogging" process, however, will require substantial efforts and a radical departure from "business-as-usual" trajectories and policies.

The primary-energy mix of this "hydrogen economy" decarbonizes at a fast pace. This trend is combined with substantial improvements of energy intensity resulting in considerable reductions of GHG emissions and, consequently, in relatively low climate change impacts. Still, the path followed in the $\mathrm{B} 1-\mathrm{H}_{2}$ world may not be enough to protect against high climate sensitivities and additional actions may be required. Hydrogen production, however, enables the capture and subsequent sequestration of carbon and, thus, opens new possibilities. This highlights the key role that hydrogen could play to "hedge" against the risks of uncertain climate change. Pursuing the penetration of hydrogen within the current hydrocarbon-based energy system, while being compatible with the dominant technological regime, could pave the way for the long-term transition to an energy system with low release of carbon to the atmosphere.

The unfolding of a sustainable hydrogen-based energy system such as the one portrayed here could bring profound changes to the current energy markets and standard business practices. In particular, the emergence of fuel cells and other distributed energy alternatives could alter fundamentally the structure of the power generation and transportation business, driving to the creation of new products and values, service standards, innovative business partnerships, etc. Fuel cells have significant potential to become an important element of the portfolio of options to meet ever-increasing demands for energy services while responding to more stringent reliability and power quality standards, mounting environmental constraints, cost-effectiveness pressures and other challenges that energy systems will face in the future. However, their successful diffusion requires a coordinated strategy in different market segments, which could allow tapping potential synergies and benefiting from cost reductions resulting from economies-of-volume and technological learning processes [33].

Clearly, a number of technological, institutional, political and social hurdles stay in the way of a transition toward a sustainable hydrogen-based global energy system. Achieving the large-scale transformations that would result in a clean and sustainable hydrogen-based energy future requires substantial efforts in a number of fields and the involvement of many different social actors. In particular, the combination of government measures and business actions is necessary to stimulate the growth of a sustainable 
hydrogen energy industry, the commercialization of the technologies and the development of a supporting infrastructure [33]. Among other actors, current energy supply companies could become prime players in the transition, if they recognize the challenges and are able to harness the opportunities that hydrogen-based technologies bring with them.

Together with other activities, international partnerships on research, development, demonstration and deployment (RD3, [5]) are necessary for a successful development of hydrogen technologies and their introduction into the marketplace. International public-private collaboration on RD3 would contribute to share costs and risks of R\& D and demonstration projects, identify and exploit niche market opportunities and implement buy-down strategies to ensure that these technologies will move along their learning curves. They could also facilitate technology transfer and access to attractive markets, key issues for speeding up the global deployment of a cluster of cleaner and more efficient hydrogen-based technologies.

\section{Acknowledgements}

This collaborative study has been sponsored by the Tokyo Electric Power Company (TEPCO). We would like to thank Leo Schrattenholzer, Project Leader of the Environmentally Compatible Energy Strategies Project at IIASA, Takashi Okano, Research Group Leader of the Corporate Planning Department at TEPCO, and Akifusa Hagiwara, Material Science Group Leader of the Energy and Environmental R\& D Center at TEPCO for their continued support and their very useful comments on the draft versions. We would also like to extend our appreciation to Pat Wagner from IIASA for her editorial assistance and encouragement.

\section{Appendix}

Aggregate technologies in the electricity generation sector are given in Table 2

\section{References}

[1] IEA (International Energy Agency). Towards a sustainable energy future. Paris, France: International Energy Agency (IEA), 2001.

[2] Riahi K, Roehrl RA, Schrattenholzer L, Miketa A. Technology clusters in sustainable development scenarios. Progress Report of Environmental Issue Groups, International Forum of the Collaboration Projects in Spring 2001, Tokyo, Japan.

[3] Ogden J. Prospects for building a hydrogen energy infrastructure. Annu Rev Energy Environ 1999;24:227-79.

[4] Elam C, Padró C. International Energy Agency agreement on the production and utilization of hydrogen. Proceedings of the 2001 US Department of Energy (DOE) Hydrogen Program Review, NREL/CP-570-30535, 2001.
[5] PCAST (President's Committee of Advisors on Science and Technology). Powerful partnerships: the federal role in international co-operation on energy innovation. President's Committee of Advisors on Science and Technology. Panel on International Co-operation in Energy Research, Development, Demonstration and Deployment, Washington, USA, 1999.

[6] DOE (Department of Energy). A multi-year plan for the hydrogen R\& D program. Rationale, structure and technology roadmaps. Office of Power Delivery and Office of Power Technologies, US Department of Energy, 1999.

[7] Lovins A, Williams B. A strategy for the hydrogen transition. Paper presented at the 10th Annual US Hydrogen Meeting, National Hydrogen Association, Vienna, Virginia, US, 1999.

[8] Marchetti C. On hydrogen and energy systems. IIASA Research Report, International Institute for Applied Systems Analysis (IIASA), Laxenburg, Austria, 1976.

[9] Marchetti C. How to solve the $\mathrm{CO}_{2}$ problem without tears. Int J Hydrogen Energy 1989;14(8):21-45.

[10] Dunn S. Hydrogen futures: towards a sustainable energy system. Worldwatch paper 157. Washington, DC, USA: Worldwatch Institute, 2001.

[11] SRES (Special Report on Emission Scenarios). A special report on emissions scenarios for working group III of the Intergovernmental Panel on Climate Change (IPCC). Cambridge, UK: Cambridge University Press, 2000.

[12] Grootaert C. Social capital: the missing link? Social Capital Initiative. Working Paper No. 3. Washington, DC, USA: World Bank, 1998.

[13] Messner S, Schrattenholzer L. MESSAGE-MACRO: linking an energy supply model with a macroeconomic module and solving it iteratively Energy 2000;25:267-82.

[14] Lutz W, editor. The future population of the world: what can we assume today? 2nd ed. London: Earthscan, 1996.

[15] Lutz W, Sanderson W, Scherbov S. The end of world population growth. Nature 2001;412.

[16] Maddison A. Monitoring the world economy 1820-1992. Paris, France: Development Centre of the Organisation for Economic Co-operation and Development (OECD), 1993.

[17] McDonald A, Schrattenholzer L. Learning rates for energy technologies. Energy Policy 2001;29(4):255-61.

[18] Harmon C. Experience curves of photovoltaic technology. IIASA Interim Report, IR-00-014, Laxenburg, Austria, 2000.

[19] Barreto L, Makihira A, Riahi K. Medium and long-term demand and supply prospects for fuel cells: the hydrogen economy and perspectives for the 21st century. Final Report on the TEPCO-IIASA Collaborative Study, 2002.

[20] Riahi K, Roehrl AR. Energy technology strategies for carbon dioxide mitigation and sustainable development. Environ Econ Policy Stud 2000;3(2):89-123.

[21] Rogner HH. An assessment of World hydrocarbon resources. Annu Rev Energy Environ 1997;22:217-62.

[22] Nakićenović N, Grübler A, McDonald A, editors. Global energy perspectives. Cambridge, UK: Cambridge University Press, 1998.

[23] Nakićenović N. Freeing energy from carbon. Daedalus 1996;125(3):95-112.

[24] Morita T, Lee H-C. IPCC SRES database, version 0.1, Emission Scenario Database prepared for IPCC Special Report on Emission Scenarios, 1998. < http://www-cger.nies. go.jp/cger-e/db/ipcc.html > .

[25] Nakićenović N, Gritsevskyi A, Grübler A, Riahi K. Global natural gas perspectives. International Gas Union (IGU) and 
International Institute of Applied Systems Analysis (IIASA), Published for the IGU Kyoto Council Meeting, Kyoto, Japan, October 2000.

[26] Turkenburg W, Beurskens J, Faaij A, Fraenkel P, Fridleifsson I, Lysen E, Mills D, Moreira J, Nilsson L, Schaap A, Sinke W. Renewable energy technologies. In: Goldemberg $\mathbf{J}$, ed. World energy assessment: energy and the challenge of sustainability. [Chapter 7] Washington/New York, US: UNDP/WEC/UNDESA (United Nations Development Programme, World Energy Council, UN Department of Economic and Social Affairs), 2001, ISBN: 92-1-126126-0, [Chapter 7].

[27] Harmon C. Experience curves of photovoltaic technology. Interim Report IR-00-014. International Institute for Applied Systems Analysis, Laxenburg, Austria, 2000.

[28] Neij L. Cost dynamics of wind power. Energy Int J 1999;24:375-89.

[29] Friedland R, Speranza AJ. Hydrogen production through electrolysis. Proceedings of the 2001 DOE Hydrogen Program Review, NREL/CP-570-30535, 2001.

[30] Argote L, Epple D. Learning curves in manufacturing. Science 1990;247:920-4.

[31] Gritsevskyi A, Nakicenovic N. Modelling uncertainty of induced technological change. Energy Policy 2000;28:907-21.

[32] Dunn S. Micropower: the next electrical era. Worldwatch Paper 151. Washington, DC, USA: Worldwatch Institute, 2000.

[33] NHA (National Hydrogen Association). Strategic plan for the hydrogen economy: the hydrogen commercialization plan, 2000. < http://www.hydrogenus.com/commpln.htm> .
[34] Riahi K, Roehrl RA. Greenhouse gas emissions in a dynamics-as-usual scenario of economic and energy development. Technol Forecast Soc Change 2000;63(3):175205.

[35] IPCC (Intergovernmental Panel on Climate Change). Climate change 1995: impacts, adaptations, and mitigation of climate change: scientific-technical analyses. In: Watson RT, Zinyowera MC, Moss RH, editors. Contribution of working group II to the second assessment report of the Intergovernmental Panel on Climate Change (IPCC). Cambridge, UK: Cambridge University Press, 1996.

[36] Wigley TML, Raper SCB. Model for the assessment of greenhouse-gas induced climate change (MAGICC version 2.3.). University of East Anglia, UK: The Climate Research Unit, 1997.

[37] Jiang K, Masui T, Morita T, Matsuoka Y. Long-term GHG emission scenarios for Asia-Pacific and the world. Technol Forecast Soc Change 2000;63(3):207-29.

[38] Fenhann J. Industrial non-energy, non- $\mathrm{CO}_{2}$ greenhouse gas emissions. Technol Forecast Soc Change 2000;63(3): 313-34.

[39] IPCC (Intergovernmental Panel on Climate Change). Summary for policymakers (SPM): climate change 2001: the scientific basis. Geneva, Switzerland: IPCC, 2001.

[40] Obersteiner M, Azar C, Kauppi PE, Moellersten K, Moreira J, Nilsson S, Read P, Riahi K, Schlamadinger B, Yamagata Y, Yan J, Van Ypersele JP. Managing climate risk. Lett Sci 2001;294:785.

[41] Goldemberg J. Leapfrog energy technologies. Energy Policy 1998;26(10):729-41. 